\title{
The expression of functionally-coupled $\mathrm{B}_{2}$-bradykinin receptors in human corneal epithelial cells and their pharmacological characterization with agonists and antagonists
}

\author{
$*,+$ T.K. Wiernas, ${ }^{*}+$ B.W. Griffin $\& *^{*,+1}$ N.A. Sharif \\ *Molecular Pharmacology Unit, Alcon Laboratories, Inc., 6201 South Freeway, Fort Worth, Texas 76134 and $\dagger$ Department of \\ Pharmacology, University of North Texas Health Sciences Center, Fort Worth, Texas, U.S.A.
}

1 Bradykinin (BK) and Lys-BK are peptides which are released at high nanomolar concentrations into the tear-film of ocular allergic patients. We hypothesized that these peptides may activate specific receptors on the ocular surface, especially the corneal epithelium (CE) and thus the CE cells may represent a potential target tissue for these kinins.

2 The purpose of the present studies, therefore, was to determine the presence of and the pharmacological characteristics of bradykinin receptors on normal cultured primary and SV40 virustransformed human corneal epithelial (CEPI) cells by use of the accumulation of $\left[{ }^{3} \mathrm{H}\right]$-inositol phosphates $\left(\left[{ }^{3} \mathrm{H}\right]-\mathrm{IPs}\right)$ as a bioassay.

3 Bradykinin (BK) induced a maximal $1.95 \pm 0.24$ fold $(n=17)$ and $2.51 \pm 0.29$ fold $(n=26)$ stimulation of $\left[{ }^{3} \mathrm{H}\right]$-IPs accumulation in normal, primary (P-CEPI) and SV40-immortalized (CEPI-17-CL4) cells, respectively. This contrasted with a maximal $3.2-4.5$ fold and $2.0-2.9$ fold stimulation by histamine $(100 \mu \mathrm{M})$ and platelet activating factor $(100 \mathrm{nM})$ in both cell-types, respectively.

4 The molar potencies of BK and some of its analogues in the CEPI-17-CL4 cells were as follows: BK $\left(\mathrm{EC}_{50}=3.26 \pm 0.61 \mathrm{nM}, \quad n=18\right), \quad$ Lys-BK $\left(\mathrm{EC}_{50}=0.95 \pm 0.16 \mathrm{nM}, \quad n=5\right)$, Met-Lys-BK $\left(\mathrm{EC}_{50}=2.3 \pm\right.$ $0.42 \mathrm{nM}, n=5)$, Ile-Ser-BK $\left(\mathrm{EC}_{50}=5.19 \pm 1.23 \mathrm{nM}, n=6\right), \mathrm{Ala}^{3}$-Lys-BK $\left(\mathrm{EC}_{50}=12.7 \pm 2.08 \mathrm{nM}, n=3\right)$, Tyr $^{8}-\mathrm{BK} \quad\left(\mathrm{EC}_{50}=19.3 \pm 0.77 \mathrm{nM}, \quad n=3\right), \quad \mathrm{Tyr}^{5}-\mathrm{BK} \quad\left(\mathrm{EC}_{50}=467 \pm 53 \mathrm{nM}, \quad n=4\right) \quad$ and $\operatorname{des}_{-}-\mathrm{Arg}^{9}-\mathrm{BK}$ $\left(\mathrm{EC}_{50}=14.1 \pm 2.7 \mu \mathrm{M}, n=4\right)$. The potencies of BK-related peptides in normal, P-CEPI cells were similar to those found in transformed cells, thus: $\mathrm{BK}, \mathrm{EC}_{50}=2.02 \pm 0.69 \mathrm{nM}(n=7)$, Tyr ${ }^{8}-\mathrm{BK}$, $\mathrm{EC}_{50}=14.6 \pm 2.7 \mathrm{nM}(n=3), \quad \mathrm{Tyr}^{5}=\mathrm{BK}, \quad \mathrm{EC}_{50}=310 \pm 70 \mathrm{nM}(n=4)$ and des-Arg${ }^{9}-\mathrm{BK}, \mathrm{EC}_{50}=12.3 \pm$ $3.8 \mu \mathrm{M}(n=3)$.

5 The bradykinin-induced responses were competitively antagonized by the $\mathrm{B}_{2}$-receptor selective $\mathrm{BK}$ antagonists, Hoe-140 (D-Arg- $\left[\mathrm{Hyp}^{3}, \mathrm{Thi}^{5}, \mathrm{D}-\mathrm{Tic}^{7}, \mathrm{Oic}^{8}\right] \mathrm{BK}$; Icatibant; molar antagonist potency $=2.9 \mathrm{nM}$; $\mathrm{pA}_{2}=8.54 \pm 0.06, \quad n=4 ; \quad$ and slope $\left.=1.04 \pm 0.08\right)$ and $\mathrm{D}-\mathrm{Arg}^{0}\left[\mathrm{Hyp}^{3}, \mathrm{Thi}^{5,8}, \mathrm{DPhe}^{7}\right]-\mathrm{BK} \quad\left(K_{\mathrm{B}}=371 \mathrm{nM}\right.$; $\left.\mathrm{p} K_{\mathrm{B}}=6.43 \pm 0.08, n=4\right)$ in CEPI-17-CL4 cells. The antagonist potency of Hoe-140 against BK in normal, P-CEPI cells was $8.4 \pm 1.8 \mathrm{nM}\left(\mathrm{p} K_{\mathrm{i}}=8.11 \pm 0.12, n=4\right)$, this being similar to the potency observed in the immortalized cells.

6 This rank order of potency of agonist BK-related peptides, coupled with the antagonism of the BKinduced $\left[{ }^{3} \mathrm{H}\right]$-IPs by the specific $\mathrm{B}_{2}$-receptor antagonists, strongly suggests that a $\mathrm{B}_{2}$-receptor subtype is involved in mediating functional phosphoinositide (PI) responses in the CEPI-17-CL4 and P-CEPI cells. 7 In conclusion, these data indicate that the P-CEPI and CEPI-17-CL4 cells express BK receptors of the $\mathrm{B}_{2}$-subtype coupled to the PI turnover signal transduction pathway. The CEPI-17-CL4 cells represent a good in vitro model of the human corneal epithelium in which to study further the role of BK receptors in its physiology and pathology, such as in allergic/inflammatory conditions, potential wound healing and other functions of the cornea.

Keywords: Bradykinin; cornea; corneal epithelium; inflammation; conjunctivitis; Hoe-140; bradykinin receptors

\section{Introduction}

The corneal epithelium, together with the tear-film covering the surface of the eye, serve critical protective and light refractive functions (Beuerman et al., 1989; Rosenbaum et al., 1995; Watanabe et al., 1995). As such, the corneal epithelium provides a first line of defence against noxious pathogens, allergens, pollutants and other undesirable airborne chemicals. Exposure to such agents initiates a cascade of inflammatory/ allergic reactions on the ocular surface characterized by redness, oedema and itching such as observed in allergic conjunctivitis, a type I hypersensitivity reaction (Allansmith \& Ross, 1988; Proud et al., 1990; Abelson \& Schaefer, 1993). The neovascularization (BenEzra et al., 1990), fibrosis and scarring (Abelson \& Schaefer, 1993; Proia, 1994) that often accom-

\footnotetext{
${ }^{1}$ Author for correspondence at: Head Molecular Pharmacology Unit, Alcon Laboratories, Inc. (R2-19), 6201 South Freeway, Fort Worth, TX 76134-2099, U.S.A.
}

panies chronic corneal inflammation can result in serious loss of visual acuity and can lead to blindness.

Allergic provocation of the human ocular surface, in particular the conjunctiva, leads to the liberation of relatively high concentrations of numerous mast cell mediators including histamine, platelet activating factor (PAF), various prostanoids and leukotrienes, and kinin peptides such as bradykinin (BK; $\left.\mathrm{Arg}^{1}-\mathrm{Pro}^{2}-\mathrm{Pro}^{3}-\mathrm{Gly}^{4}-\mathrm{Phe}^{5}-\mathrm{Ser}^{6}-\mathrm{Pro}^{7}-\mathrm{Phe}^{8}-\mathrm{Arg}^{9}\right)$ and LysBK (kallidin) into the tear-film bathing the cornea and conjunctiva (Proud et al., 1990; Abelson \& Schaefer, 1993). Although there is firm evidence implicating an important role of histamine in mediating conjunctival and possibly corneal allergic and inflammatory reactions (Allansmith \& Ross, 1988; Abelson \& Schaefer, 1993), the role of BK and related peptides in such ocular diseases is less well defined. BK and Lys-BK are formed and released during injury, trauma and following noxious or allergic reactions in many organs in the body (Regoli et al., 1990; Hall, 1992; Marceau, 1995). These peptides 
produce powerful pro-inflammatory effects by increasing vasodilatation and vascular permeability, promotion of fluid and ion secretion from epithelial cells and eliciting pain at the site of the noxious challenge (Sharma, 1993; Dray \& Perkins, 1993). Two major $B K$ receptor subtypes $\left(B_{1}\right.$ and $\left.B_{2}\right)$ are known to mediate these diverse effects of $\mathrm{BK}$ and related peptides (Regoli et al., 1990; Hall, 1992; Marceau, 1995). Both subtypes are G-protein coupled receptors that transduce their effects by stimulating phospholipase $\mathrm{C}$ and thus causing phosphoinositide (PI) hydrolysis (Sharif et al., 1988; Butt et al., 1995; Smith et al., 1995; Sharif \& Xu, 1996). The latter PI turnover leads to the generation of inositol phosphates and diacylglycerol (Berridge \& Irvine, 1984; Abdel-Latif, 1995). The inositol trisphosphate mobilizes intracellular calcium from the endoplasmic reticulum in the cell interior (Berridge \& Irvine, 1984; Ransom et al., 1991) which then activates calmodulin and other proteins to initiate the subsequent biochemical reactions in the cell that culminate in the final biological response such as hormone or neurotransmitter release or tissue contraction (Berridge \& Irvine, 1984). While the $\mathrm{B}_{2}$-subtype exists under normal physiological and pathological conditions, the $\mathrm{B}_{1}$-subtype is only induced under injurious and/or pathological conditions or during in vitro incubation (Regoli et al., 1990; Hall, 1992; Sharma, 1993). However, constitutively expressed $\mathrm{B}_{1}$-receptors are found in certain cell-lines (e.g. W138 human lung fibroblasts) (Phagoo et al., 1996).

As for the ocular effects of BK, intracamerally injected BK in rabbits causes miosis, raises intraocular pressure and induces breakdown of the blood-aqueous barrier (Cole, 1974; Cole \& Ungar, 1974; Bynke et al., 1983; Wahlestedt et al., 1985). Recent clinical studies have demonstrated the release of $200 \mathrm{nM} \mathrm{BK}$ and Lys-BK into the tears of allergic human patients subjected to an allergic conjunctival challenge (Proud et al., 1990). Topically applied BK also causes plasma extravasation in the guinea-pig conjunctiva (Hall et al., 1995; Figini et al., 1995) and in other ocular tissues (Elliot et al., 1995), and signal transduction studies have shown that human conjunctival epithelial cells respond to $\mathrm{BK}$ and stimulate the production of inositol phosphates (Sharif et al., 1997a). Although recent studies have demonstrated the presence of a robust kallikrein-kinin system (including mRNAs for $B_{1}$ and $\mathrm{B}_{2}$ receptors) in human ocular tissues such as ciliary muscle, retinal neurones, choroid and ciliary body (Ma et al., 1996), no information is available for the cornea.

Therefore, in the present studies we have investigated whether human cultured corneal epithelial (CEPI) cells (primary and SV40-virus-immortalized), which would also be exposed to the BK and Lys-BK in the tears of ocular allergic patients (Proud et al., 1990), respond to these peptides and, thus, whether these ocular surface cells are also targets of these peptides released from conjunctival mast cells during ocular allergic reactions such as during conjunctivitis. Since the supply of normal, primary human CEPI cells (P-CEPI) is limited and these cells do not divide and proliferate over more than a few passages (Kahn et al., 1993), we decided to use previously SV40 virus-immortalized human CEPI cells (CEPI-17-CL4) (Sharif et al., 1997b; Offord et al., 1997) as a model system for studying the actions of BK and its analogues. However, in order to ensure that the immortalized cells faithfully represented the primary cells, we also conducted numerous agonist and antagonist studies on normal, primary (P-CEPI) cell cultures from many different human post-mortem donors.

A preliminary account of the studies presented in this paper has been recently published in abstract form (Sharif et al., 1997c).

\section{Methods}

\section{Human corneal epithelial cell isolation and cultures}

The procedures used were similar to those described for the isolation of human conjunctival epithelial cells (Sharif et al., 1997a). Briefly, human corneas were aseptically dissected from numerous post-mortem donor eyes (up to 17 donors; ages 3-95 years old) within $8-12 \mathrm{~h}$ of death and transported from eye banks in ice-cold Dexol or Optisol corneal preservation medium (Sharif et al., 1997b). The corneas from different donors were kept separate and rinsed in phosphate buffered saline (PBS) before being treated with dispase, $10 \mathrm{u} \mathrm{ml}^{-1}$ in $50 \%$ Hanks buffered salts and kerotinocyte growth medium (KGM) containing $0.05 \mathrm{mM}$ calcium at $4^{\circ} \mathrm{C}$ for $24-48 \mathrm{~h}$. The KGM was prepared by adding a commercially available bullet kit (bovine pituitary extract $30 \mu \mathrm{g} \mathrm{ml}^{-1}$, hydrocortisone $0.5 \mu \mathrm{g} \mathrm{ml}^{-1}$, amphotericin B $0.05 \mu \mathrm{g} \mathrm{ml}^{-1} /$ gentamicin $50 \mu \mathrm{g} \mathrm{ml}^{-1}$, insulin $5 \mu \mathrm{g} \mathrm{ml}^{-1}$, transferrin $10 \mu \mathrm{g} \mathrm{ml}^{-1}$, murine epidermal growth factor $10 \mu \mathrm{g} \mathrm{ml}^{-1}$ ) and $0.05 \mathrm{mM}$ calcium chloride to keratinocyte basal medium (KBM). After this incubation, the epithelium was removed with a gentle sweep across the tissue with a scalpel blade. The tissue was gently triturated to generate individual cells which were then washed in Dulbecco's modified Eagle medium (DMEM) containing $10 \%$ foetal bovine serum by a low speed centrifugation/resuspension procedure. The cell pellet was resuspended in low calcium $(0.05 \mathrm{mM}) \mathrm{KGM}$ medium, plated into T25 flasks (previously coated with collagen type IV and fibronectin) and incubated at $37^{\circ} \mathrm{C}$ under a humidified atmosphere of $95 \% \mathrm{O}_{2} /$ $5 \% \mathrm{CO}_{2}$. The medium was changed $24 \mathrm{~h}$ later and every 2 days thereafter. The cells became confluent in approximately 10 days at which point they were sub-cultured (passage 1; P1) by rinsing with PBS, incubating in dispase for up to $1 \mathrm{~h}$ until the cells detached, washing in DMEM by centrifugation and plating on collagen-coated 24 -well plates. All subsequent experiments for PI turnover were performed with the P1 cells.

\section{Immortalized CEPI cells}

The procedures for the SV40 virus-induced transformation and the initial genetic, morphological and preliminary pharmacological characterization of the primary (P-CEPI) and the later immortalized (CEPI-17-CL4) cells have been recently described (Kahn et al., 1993; Araki-Sasaki et al., 1995; Offord et al., 1997; Sharif et al., 1997b). Briefly, sub-confluent P-CEPI cells were cultured in KGM (supplemented hormone epithelial medium) in a $75 \mathrm{~cm}$ flask and infected with a recombinant SV40-retrovirus vector (p1/SV40U19) as previously described (Pfeifer et al., 1993). The plasmid resulting from this transfection was generated by cloning the genomic Bgl-Hpal fragment (nucleotides 5235 to 2666) of SV40 into the Bam HI site of pZIP Nep SV(X)1 vector. This fragment contained a truncated origin of replication and lacked an early promoter and polyadenylation site. It also had a mutation in the DNA binding site of the protein which prevented binding to the SV40 origin of replication. This vector was designed to prevent infectious SV40 virus production in cells, even if recombination would restore the origin of replication. Although many clones were isolated, one of the fast-growing clones (CEPI-17 clone 4; CEPI-17-CL4) was selected for the initial genetic, morphological and preliminary signal transduction studies (Offord et al., 1997; Sharif et al., 1997b). The latter studies demonstrated that the primary and immortalized cells were essentially the same with respect to the cell cytoskeletal markers (cytokeratins) and both cell types exhibited a similar pharmacological responsiveness (e.g. to histamine and plateletactivating factor, PAF), thus rendering the immortalized cells as a representative model system for studying the effects of various chemicals on human CEPI cells.

In the present studies, we utilized CEPI-17-CL4 cells of passage numbers $28-130$ cultured under identical conditions to the P-CEPI cells, except that we found the CEPI-17-CL4 cells to grow better in the medium containing penicillin $\left(10,000 \mathrm{u} \mathrm{ml}^{-1}\right)$ and streptomycin $\left(10,000 \mu \mathrm{g} \mathrm{ml}^{-1}\right)$ instead of amphotericin $\mathrm{B} /$ gentamicin and with $0.15 \mathrm{mM} \mathrm{CaCl}_{2}$ instead of $0.05 \mathrm{mM} \mathrm{CaCl}_{2}$ in the medium. The CEPI-17-CL4 cells also preferred growing in $0.1 \%$ gelatin-coated flasks before being passaged. 


\section{Phosphoinositide (PI) turnover studies}

PI turnover induced by stimulation of phospholipase $\mathrm{C}$ in $\mathrm{P}$ CEPI and CEPI-17-CL4 cells was performed as previously described (Sharif \& Whiting, 1993) with minor modifications (Sharif et al., 1994; Sharif \& Xu, 1996). Briefly, the P-CEPI or CEPI-17-CL4 cells $\left(2.5 \times 10^{5}\right.$ cells/well $)$ cultured in 24 -well plates were incubated with $\left[{ }^{3} \mathrm{H}\right]$-myo-inositol $\left(2 \mu \mathrm{Ci} \mathrm{ml}^{-1}, 15-\right.$ $17 \mathrm{Ci} \mathrm{mmol}^{-1}$ ) in DMEM for $24 \mathrm{~h}$ at $37^{\circ} \mathrm{C}$ in order to label the cell membrane lipids. After this time, the medium was aspirated and the cells exposed to $\mathrm{BK}$ and related agonist peptides $(0.01 \mathrm{nM}-30 \mu \mathrm{M})$ in DMEM/F-12 medium $(+15 \mathrm{~mm}$ HEPES buffer) containing $10 \mathrm{mM} \mathrm{LiCl}$ for $60 \mathrm{~min}$ at $37^{\circ} \mathrm{C}$ in order to stimulate the production and accumulation of $\left[{ }^{3} \mathrm{H}\right]-$ inositol phosphates $\left(\left[{ }^{3} \mathrm{H}\right]-\mathrm{IPs}\right)$ (Berridge et al., 1982; Sharif et al., 1996). To determine the potencies of the antagonists, the latter drugs were added to the cells $30 \mathrm{~min}$ before the addition of BK or other agonists. The medium was aspirated at the end of the incubation and the assay terminated by the addition of $1 \mathrm{ml}$ of ice-cold $0.1 \mathrm{M}$ formic acid. After $15 \mathrm{~min}, 0.9 \mathrm{ml}$ of the cell lysates were transferred to Econo-columns containing $1 \mathrm{ml}$ AG1 $\times 8$ ion-exchange resin in formate form. The columns were washed with $10 \mathrm{ml}$ deionized water and $8 \mathrm{ml} 50 \mathrm{mM}$ ammonium formate. The water-soluble $\left[{ }^{3} \mathrm{H}\right]-\mathrm{IPs}$ were then eluted from the columns into $20 \mathrm{ml}$ scintillation vials with $4 \mathrm{ml}$ ammonium formate $(1.2 \mathrm{M})$ prepared in $0.1 \mathrm{M}$ formic acid. A water-accepting scintillation fluid $(15 \mathrm{ml})$ was then added to the eluates and the $\left[{ }^{3} \mathrm{H}\right]$-IPs quantified by liquid scintillation spectrometry on a $\beta$-counter with Ecolume scintillation cocktail.

\section{Materials}

The different reagents, chemicals, drugs and materials used in the present studies were purchased or were gifts from the following sources: Optisol or Dexol from Chiron Ophthalmics (Irvine, CA, U.S.A.); dispase from Collaborative Biomedical (Bedford, MA, U.S.A.); KGM from Clonetics Corp (San Diego, CA, U.S.A.); culture plates from Corning/Costar (Cambridge, MA, U.S.A.) Becton Dickenson (Oxnard, CA, U.S.A.), CAFNC-matrix from Biological Research Faculty and Facility, Inc. (Ijamsville, MD, U.S.A.); all peptides were from Peninsula Labs. (Belmont, CA, U.S.A.), except Hoe-140 (Icatibant) which was a generous gift from Hoechst AG (Frankfurt, Germany); [ $\left.{ }^{3} \mathrm{H}\right]-m y o$-inositol from Amersham Corp. (Deerfield, IL, U.S.A.) and/or from Dupont-NEN (Boston, MA, U.S.A.); AG1 $\times 8$ resin and Econo-columns from Biorad (Richmond, CA, U.S.A.); gentamicin, penicillin/ streptomycin from Gibco/BRL (Grand Island, NY, U.S.A.); Ecolume scintillation cocktail from ICN (Costa Mesa, CA, U.S.A.); Origin software package from Microcal (Northampton, MA, U.S.A.).

\section{Data analysis}

The original data (d.p.m./well) were analysed by a non-linear, iterative curve-fitting computer programme (Michel \& Whiting, 1984; Sharif \& Whiting, 1991) and Origin (Sharif et al., $1996 ; 1997$ a) incorporating a logistic function. Agonist potency $\left(\mathrm{EC}_{50}\right)$ was defined as the concentration of the compound required to stimulate $50 \%$ of the maximal PI turnover response. Individual concentration-response curves for each agonist were analysed as above to obtain the potency values. However, in order to present composite data from each peptide from several experiments (e.g. Table 1), the data were normalized such that basal (unstimulated) levels of $\left[{ }^{3} \mathrm{H}\right]-$ IPs were set to zero and the maximally-stimulated levels of $\left[{ }^{3} \mathrm{H}\right]-$ IPs at the top of each of the concentration-response curves were set to $100 \%$. All intermediate levels of $\left[{ }^{3} \mathrm{H}\right]-\mathrm{IPs}$ accumulation were then calculated as a percentage of the maximal stimulation. Antagonist potencies were determined by the method of $\mathrm{Ar}$ unlakshana \& Schild (1959) (for $\mathrm{pA}_{2}$ values) by use of 3-4 antagonist concentrations. Antagonist potency was re- presented as $\mathrm{pA}_{2}(-\log$ drug dissociation constant $)$ and is defined as $-\log$ molar antagonist concentration required to shift the agonist concentration-response curve to the right by 2 fold as determined by Schild analysis (Arunlakshana \& Schild, 1959). The apparent $\mathrm{p} K_{\mathrm{B}}\left(-\log K_{\mathrm{B}}\right)$ values for antagonists were calculated according to the following Gaddum-Schild equation:

$$
K_{\mathrm{B}}=\text { (Antagonist concentration) } /
$$

((Agonist $\mathrm{EC}_{50}$ in presence of antagonist/

Agonist $\mathrm{EC}_{50}$ in absence of antagonist) - 1).

The other antagonist potency values, $K_{\mathrm{i}} \mathrm{s}$, were calculated according to the Cheng \& Prusoff (1973) equation as follows:

$\mathrm{K}_{\mathrm{i}}=$ Antagonist $\mathrm{IC}_{50} / 1+[$ Agonist concentration used/Agonist $\left.\mathrm{EC}_{50}\right]$

\section{Results}

BK stimulated PI turnover was linear over time up to $90 \mathrm{~min}$ $(n=3)$ (data not shown) and thus all subsequent studies were conducted for $60 \mathrm{~min}$ at $37^{\circ} \mathrm{C}$. BK induced the production of $\left[{ }^{3} \mathrm{H}\right]-\mathrm{IPs}$ in both the P-CEPI and CEPI-17-CL4 cells in a concentration-dependent manner and with similar magnitudes of their respective responses (Figure 1; Table 1). Bradykinin (BK; $0.1-1 \mu \mathrm{M})$ induced a maximal $1.95 \pm 0.2$ fold $(n=17)$ and $2.51 \pm 0.29$ fold $(n=26)$ stimulation of $\left[{ }^{3} \mathrm{H}\right]-$ IPs accumulation in normal, primary (P-CEPI) and SV40-immortalized (CEPI-17CL4) cells, respectively. This contrasted with a maximal $3.2-$ 4.5 fold and $2.0-2.9$ fold stimulation by histamine $(100 \mu \mathrm{M})$ and platelet activating factor $(\mathrm{PAF} ; 100 \mathrm{nM})$, respectively (data not shown). The maximal amounts of $\left[{ }^{3} \mathrm{H}\right]$-IPs produced by BK relative to basal levels were: basal $=2228 \pm 327$ d.p.m. $/$ well $(n=17) ; \mathrm{BK}=4353 \pm 461$ d.p.m./well $(n=17$ in P-CEPI cells $)$;

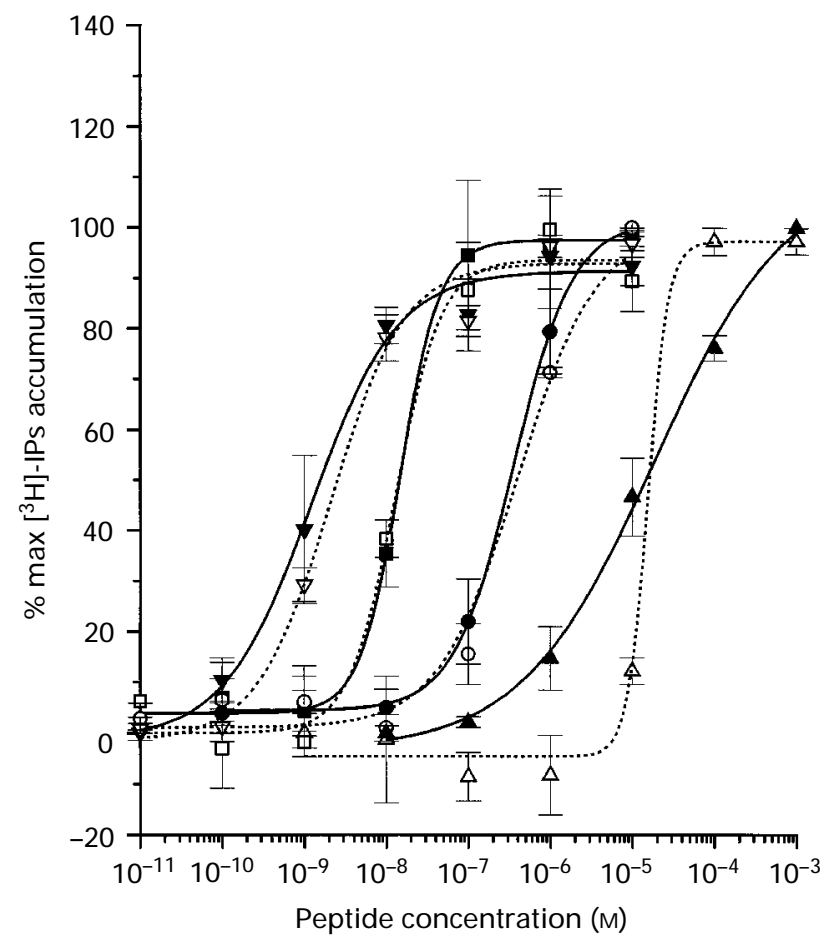

Figure 1 Concentration-response curves for $(\boldsymbol{\nabla}, \nabla)$ BK, $(\boldsymbol{\square}, \square)$, Tyr $^{8}$-BK, $(\boldsymbol{O}, \bigcirc)$ Tyr $^{5}$-BK and $(\boldsymbol{A}, \triangle)$ des-Arg ${ }^{9}$-BK in P-CEPI (solid symbols) and CEPI-17-CL4 (open symbols) cells. Both cell types were stimulated with various concentrations of the peptides and the $\left[{ }^{3} \mathrm{H}\right]-$ inositol phosphates $\left(\left[{ }^{3} \mathrm{H}\right]-\mathrm{IPs}\right)$ produced quantified by ion exchange chromatography. Data are mean from 3-18 experiments; vertical lines show s.e.mean. 
basal $=1102 \pm 83$ d.p.m./well $(n=26) ; \mathrm{BK}=2769 \pm 358$ d.p.m. well ( $n=26$ in CEPI-17-CL4 cells).

The molar agonist potencies of $\mathrm{BK}$ and some of its analogues in the CEPI-17-CL4 cells were as follows: BK $\left(\mathrm{EC}_{50}=3.26 \pm 0.16 \mathrm{nM}, n=18\right)$, Lys-BK $\left(\mathrm{EC}_{50}=0.95 \pm\right.$ $0.16 \mathrm{nM}, n=5)$, Met-Lys-BK $\left(\mathrm{EC}_{50}=2.3 \pm 0.42 \mathrm{nM}, n=5\right)$, IleSer-BK (T-kinin, $\left.\quad \mathrm{EC}_{50}=5.19+1.23 \mathrm{nM}, \quad n=6\right), \quad \mathrm{Tyr}^{5}-\mathrm{BK}$ $\left(\mathrm{EC}_{50}=467 \pm 53 \mathrm{nM}, n=4\right)$ and des-Arg'-BK $\left(\mathrm{EC}_{50}=14.1 \pm\right.$ $2.7 \mu \mathrm{M}, n=\overline{4}$ ), all being full agonists (Figure 2; Table 1). Additional $\mathrm{BK}$ analogues were also tested with the following results: $\mathrm{Ala}^{3}$-Lys-BK $\left(\mathrm{EC}_{50}=12.7 \pm 2.08 \mathrm{nM}, n=3\right)$ and $\mathrm{Tyr}^{8}-\mathrm{BK}$ $\left(\mathrm{EC}_{50}=19.3 \pm 0.77 \mathrm{nM}, n=3\right)$, all being full agonists (Figure 3; Table 1). The potency of either $\mathrm{BK}\left(\mathrm{EC}_{50}=2.02 \pm 0.69 \mathrm{nM}\right.$, $n=7), \quad \mathrm{Tyr}^{8}-\mathrm{BK} \quad\left(\mathrm{EC}_{50}=14.6 \pm 2.7 \mathrm{nM}, \quad n=3\right), \quad \mathrm{Tyr}^{5}-\mathrm{BK}$ $\left(\mathrm{EC}_{50}=310 \pm 70 \mathrm{nM}, n=4\right)$ or des-Arg 9 -BK $\left(\mathrm{EC}_{50}=12,333 \pm\right.$
$3.844 \mathrm{nM}, n=3$ ) in normal P-CEPI cells was similar to that observed in the immortalized cells, with all these peptides being full agonists (Figure 1, Table 1).

In the presence of nanomolar concentrations of Hoe-140 (D-Arg-[Hyp $\left.{ }^{3}, \mathrm{Thi}^{5}, \mathrm{D}-\mathrm{Tic}^{7}, \mathrm{Oic}^{8}\right] \mathrm{BK}$, a $\mathrm{B}_{2}$-receptor selective antagonist, the $\log$ concentration-response curves of $\mathrm{BK}$ were dextrally shifted without a suppression of the maximal BKinduced PI turnover response in CEPI-17-CL4 cells (Figure 4). This was consistent with competitive antagonism of the BKresponses by Hoe-140. Schild analyses of the Hoe-140 antagonist data yielded apparent antagonist potencies of $2.9 \mathrm{nM}$; $\mathrm{pA}_{2}=8.54 \pm 0.06$, slope $=1.04 \pm 0.08, n=4$ (Figures 4 and 5). Antagonist data for $\mathrm{D}-\mathrm{Arg}^{0}\left[\mathrm{Hyp}^{3}, \mathrm{Thi}^{5,8}\right.$, DPhe $]$-BK in CEPI17-CL4 cells were: apparent $K_{\mathrm{b}}=371 \mathrm{nM}$; apparent $\mathrm{p} K_{\mathrm{B}}=6.43 \pm 0.08(n=4)$ (Figure 6). The antagonist potency of

Table 1 Potencies of BK-related peptides in stimulating PI turnover in human cultured primary (P-CEPI) and immortalized (CEPI-17CL4) corneal epithelial cells

\begin{tabular}{|c|c|c|}
\hline Peptide agonist & $\begin{array}{c}\text { Potency }\left(E C_{50}\right) \text { for stimulating } \\
{\left[{ }^{3} H\right]-I P S \text { accumulation in }} \\
\text { CEPI-17-CL4 cells }\end{array}$ & $\begin{array}{c}\text { Potency }\left(E C_{50}\right) \text { for stimulating } \\
\left.I^{3} \mathrm{H}\right]-I P \text { accumulation in } \\
P-C E P I \text { cells }\end{array}$ \\
\hline Lys-BK & $0.95 \pm 0.16 \mathrm{nM}$ & ND \\
\hline Met-Lys-BK & $2.31 \pm 0.42 \mathrm{~nm}$ & ND \\
\hline $\mathrm{BK}$ & $3.26 \pm 0.61 \mathrm{nм}(18)$ & $2.02 \pm 0.69 \mathrm{nM}$ \\
\hline Ile-Ser-BK (TK) & $5.19 \pm 1.23 \mathrm{nM} \quad(6)$ & ND \\
\hline $\mathrm{Ala}^{3}$-Lys-BK & $12.7 \pm 2.08 \mathrm{~nm}$ & ND \\
\hline $\mathrm{Tyr}^{8}-\mathrm{BK}$ & $19.3 \pm 0.77 \mathrm{~nm}$ & $14.6 \pm 2.7 \mathrm{~nm}$ \\
\hline $\mathrm{Tyr}^{5}-\mathrm{BK}$ & $467 \pm 53 \mathrm{~nm}$ & $310 \pm 70 \mathrm{~nm}$ \\
\hline des-Arg'-BK & $14,100 \pm 2,700 \mathrm{~nm}$ (4) & $12,333 \pm 3,844 \mathrm{~nm}(3)$ \\
\hline
\end{tabular}

Data are mean \pm s.e.mean from 3-18 independent experiments as shown for the different peptides. Potency is the molar agonist concentration required to produce $50 \%$ of the maximal stimulation of $\left[{ }^{3} \mathrm{H}\right]$-inositol phosphates $\left(\left[{ }^{3} \mathrm{H}\right]-\mathrm{IPs}\right)$ accumulation. The amino acid sequence of bradykinin for reference is: $\mathrm{Arg}^{1}-\mathrm{Pro}^{2}-\mathrm{Pro}^{3}-\mathrm{Gly}^{4}-\mathrm{Phe}^{5}-\mathrm{Ser}^{6}-\mathrm{Pro}^{7}-\mathrm{Phe}^{8}-\mathrm{Arg}^{9}$. ND $=$ not determined.

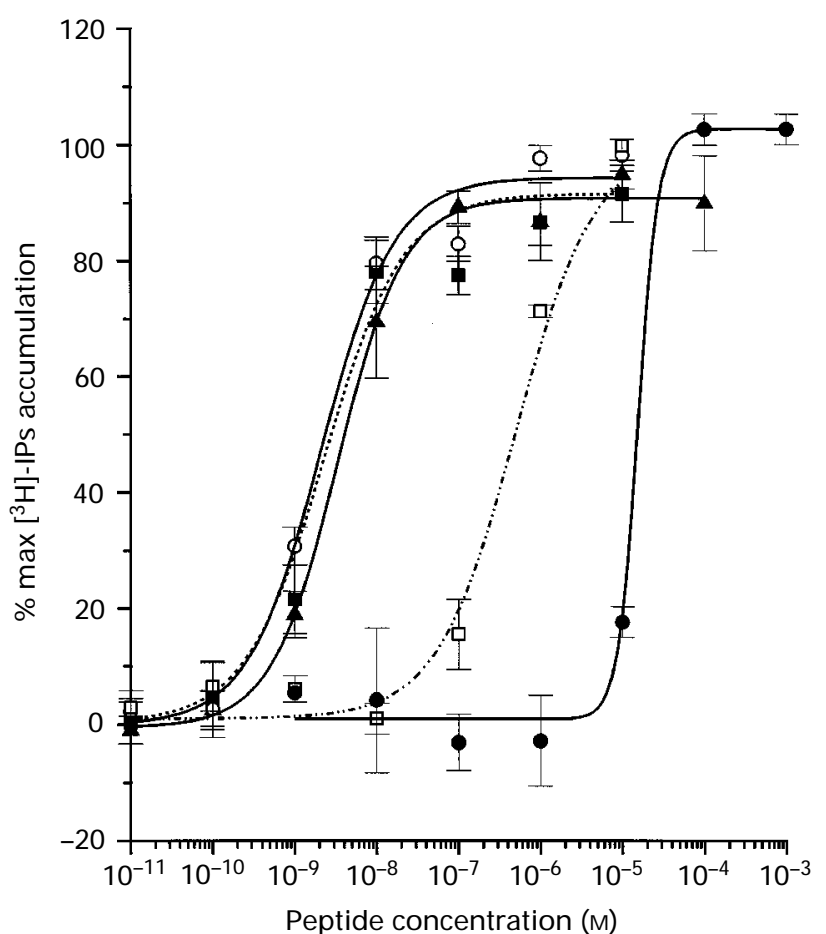

Figure 2 Concentration-response curves for $(\bigcirc)$ BK and related peptide analogues, $(\boldsymbol{\square})$ Met-Lys-BK, $(\mathbf{A})$ T-kinin, $(\square)$ Tyr $^{5}$-BK and (๑) des-Arg'-BK, in CEPI-17-CL4 cells. Cells were stimulated with various concentrations of the peptides at $37^{\circ} \mathrm{C}$, the reaction stopped and the $\left[{ }^{3} \mathrm{H}\right]$-inositol phosphates $\left(\left[{ }^{3} \mathrm{H}\right]\right.$-IPs $)$ produced quantified by ion exchange chromatography. Data are mean from 4-18 experiments; vertical lines show s.e.mean.

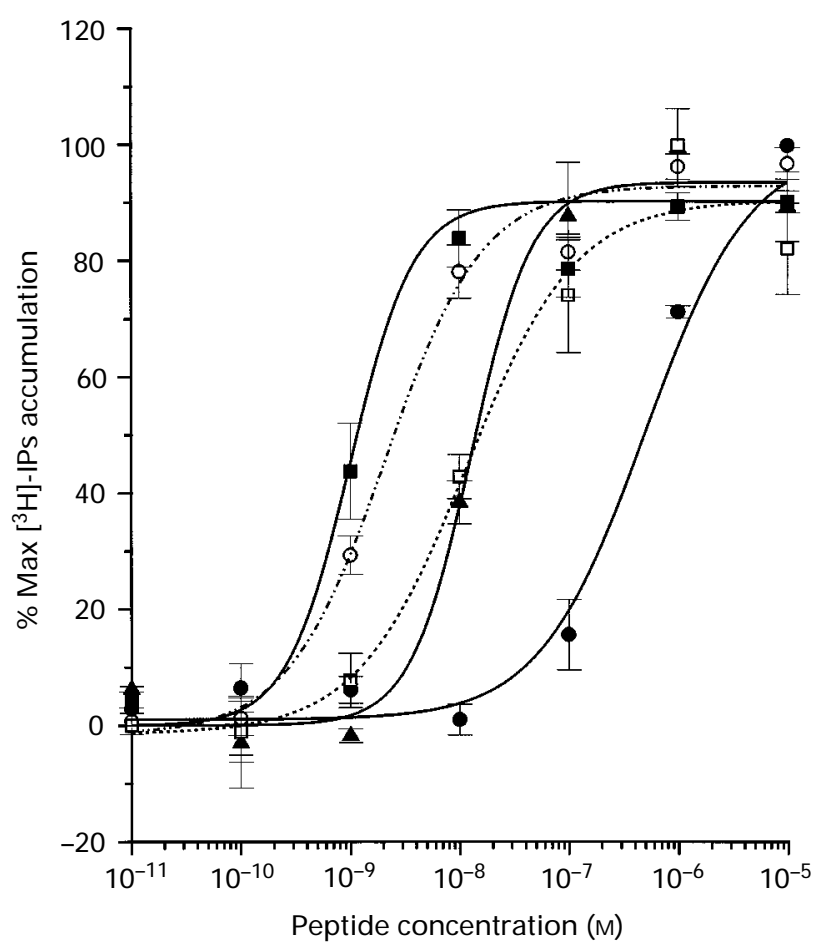

Figure 3 Concentration-response curves for $(\mathrm{O}) \mathrm{BK}$ and related peptide analogues, $(\boldsymbol{\square})$ Lys-BK, $(\boldsymbol{\Delta}) \mathrm{Tyr}^{8}-\mathrm{BK},(\square) \mathrm{Ala}^{3}-\mathrm{Lys}-\mathrm{BK}$ and () $\mathrm{Tyr}^{5}-\mathrm{BK}$, in CEPI-17-CL4 cells. Cells were stimulated with various concentrations of the peptides at $37^{\circ} \mathrm{C}$, the reaction stopped and the $\left[{ }^{3} \mathrm{H}\right]$-inositol phosphates $\left(\left[{ }^{3} \mathrm{H}\right]-\mathrm{IPs}\right)$ produced quantified by ion exchange chromatography. Data are mean from $3-18$ experiments; vertical lines show s.e.mean. 


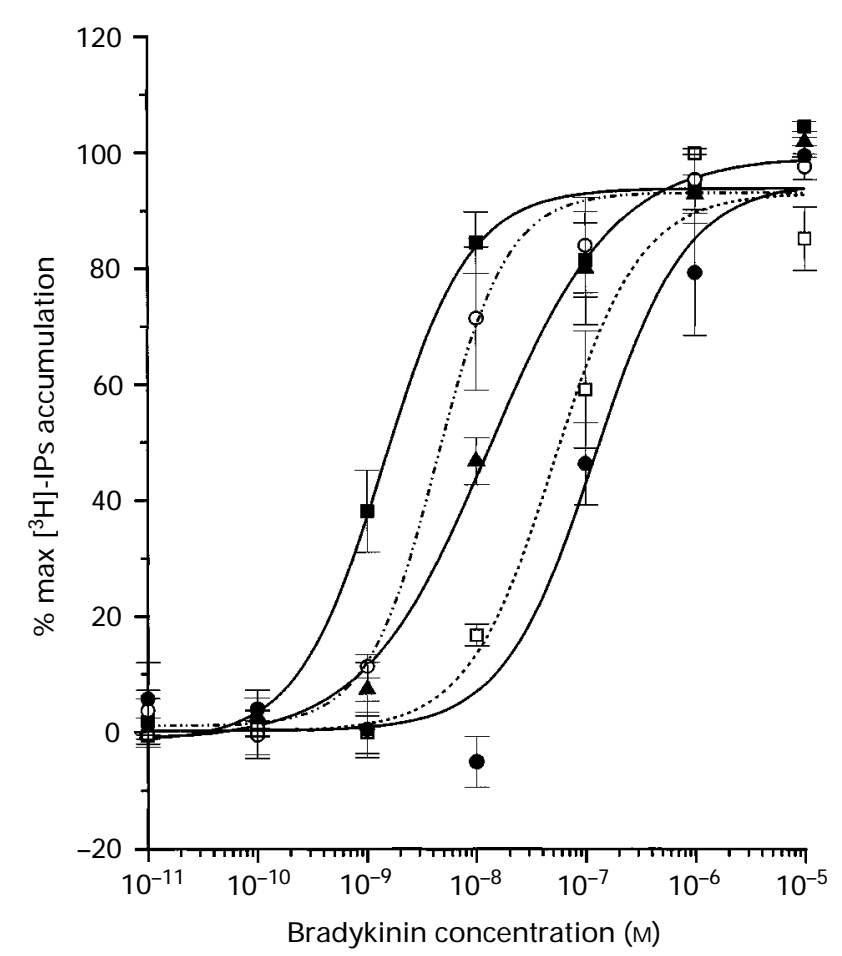

Figure 4 Concentration-response curves for BK in the absence and presence of increasing concentrations of the $\mathrm{B}_{2}$-receptor selective

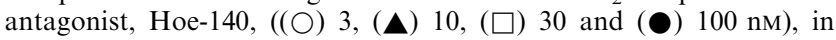
CEPI-17-CL4 cells. Data are mean from 3-5 experiments with the different antagonist concentrations; vertical lines show s.e.mean.

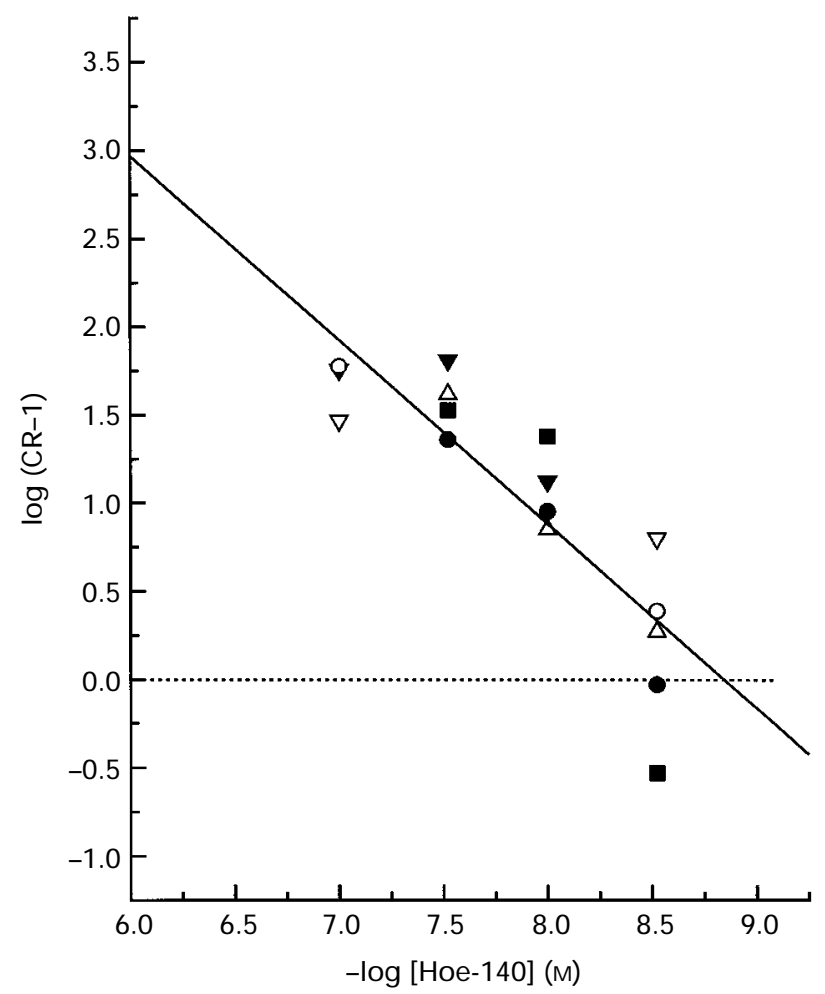

Figure 5 Schild plot for antagonism of BK-induced phosphoinositide (PI) turnover in CEPI-17-CL4 cells by Hoe-140. Data shown are the individual data points obtained from $3-5$ experiments with the different antagonist concentrations (see legend of Figure 4) with each point being derived from a single shift. The line of best-fit for all these data is shown in this plot (slope $=1.044$; correlation coefficient $=0.86$ ). The composite $\mathrm{pA}_{2}$ values from the analysis of each separate experiment are shown in the Results section.

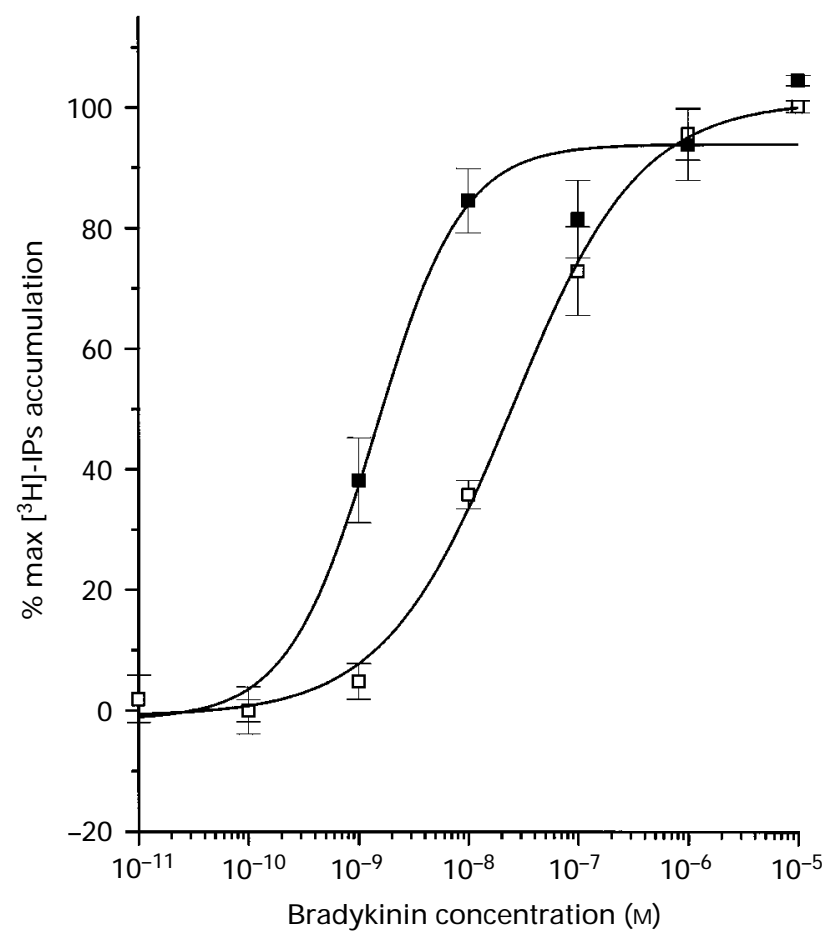

Figure 6 Concentration-response curves for BK in CEPI-17-CL4 cells in the absence ( $\square$ ) and presence $(\square)$ of $5 \mu \mathrm{M}$ of the $\mathrm{B}_{2}$-receptor selective antagonist, D-Arg ${ }^{0}\left[\mathrm{Hyp}^{3}, \mathrm{Thi}^{5,8}, \mathrm{DPhe}^{7}\right]-\mathrm{BK}$. Data are mean from 4 experiments; vertical lines show s.e.mean.

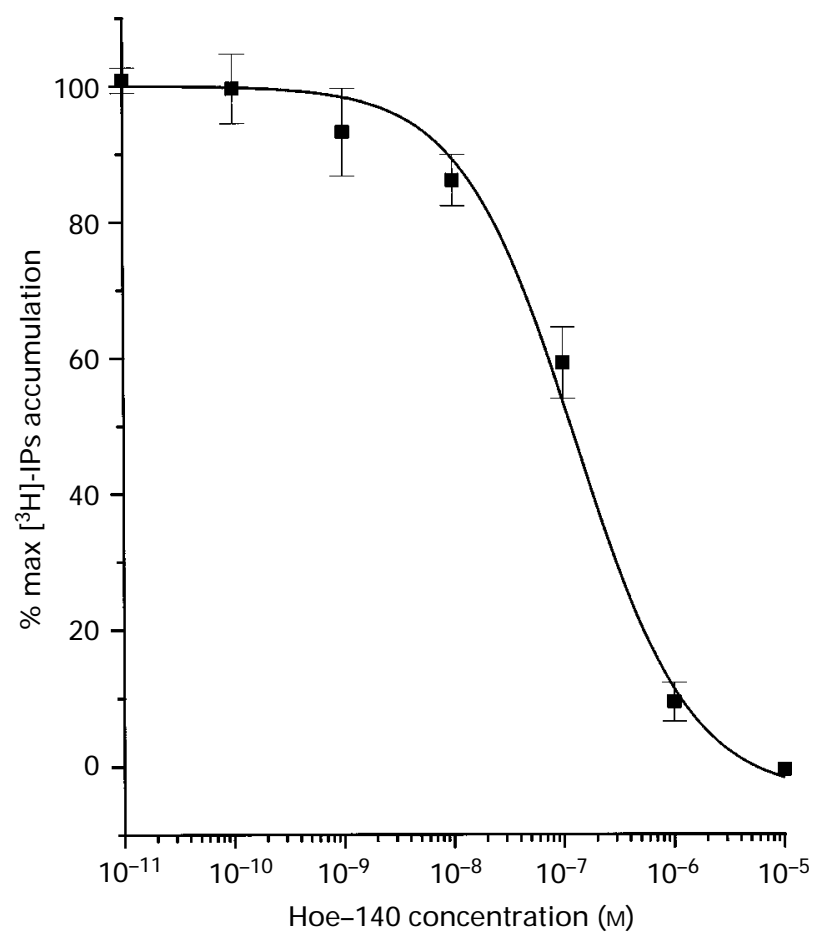

Figure 7 Effect of the $\mathrm{B}_{2}$-receptor selective antagonist, Hoe-140, on BK-induced phosphoinositide (PI) turnover in P-CEPI-17-CL4 cells. The cells were pretreated with Hoe-140 $(0.01 \mathrm{nM}-10 \mu \mathrm{M})$ and then stimulated with $100 \mathrm{~nm}$ BK. The incubation was terminated and the $\left[{ }^{3} \mathrm{H}\right]$-inositol phosphates $\left(\left[{ }^{3} \mathrm{H}\right]-\mathrm{IPs}\right)$ produced quantified by ion exchange chromatography. Data are mean from 5 experiments; vertical lines show s.e.mean. Similar data were obtained in the PCEPI cells (see Results). 
Hoe-140 against BK in P-CEPI cells was $8.4 \pm 1.8 \mathrm{nM}$ $\left(\mathrm{p} K_{\mathrm{i}}=8.11 \pm 0.12, n=4\right)$, and it was $2.7 \pm 0.76 \mathrm{nM}\left(\mathrm{p} K_{\mathrm{i}}=8.6 \pm\right.$ $0.15, n=5$ ) in CEPI-17-CL4 cells (Figure 7).

\section{Discussion}

The present studies have demonstrated the presence of functional BK receptors in cultured primary and immortalized CEPI cells (of many different passages) coupled to the production of $\left[{ }^{3} \mathrm{H}\right]-$ IPs by activation of phospholipase C. The magnitude of the BK-induced responses and the nanomolar potency of BK for stimulating PI turnover were very similar in both cell types indicating that the transformation of the cells did not alter the BK receptor binding site, signal transduction components or their coupling mechanism. This hypothesis was supported further by the observation that the potent $\mathrm{B}_{2^{-}}$ selective antagonist, Hoe-140 (Hock et al., 1991; Wirth et al., 1995), exhibited very similar potencies in blocking the BKinduced PI turnover in the primary and transformed CEPI cells, and that these potency values correlated well with the ability of Hoe-140 to antagonize a diverse range of functional responses in many different types of cells and tissues (Regoli et al., 1990; Hall, 1992; Sharif \& Xu, 1996).

The structure-activity relationship of the BK-related peptides warrants discussion since addition or deletion of amino acids at the $\mathrm{N}$ - or $\mathrm{C}$-termini of $\mathrm{BK}$ appeared to have a significant effect on the relative potency of the peptides. Thus, although addition of lysine to the $\mathrm{N}$-terminus of $\mathrm{BK}$ actually enhanced the peptide potency, addition of methionine to the Nterminus of Lys-BK reduced the potency down to that of BK itself. Such findings accord with published data from other cells and tissues (Regoli \& Barabe', 1980; Regoli et al., 1990; Hall, 1992; Marceau et al., 1994). Interestingly, Ile-Ser-BK (T-kinin) had a similar nanomolar potency to BK in stimulating PI turnover in CEPI-17-CL4 cells and this was analogous to the potency of T-kinin in contracting rat uterus strips (Gao et al., 1993) and for evoking ion secretion in rat colon (Tien et al., 1990). However, substitution of the amino acids within the BK or Lys-BK structures resulted in a dramatic loss in potency, as seen for example in $\mathrm{Ala}^{3}$-Lys-BK, $\mathrm{Tyr}^{8}-\mathrm{BK}$ and $\mathrm{Tyr}^{5}-\mathrm{BK}$, and again these are consistent with the activities of these agents seen in other systems (Regoli \& Barabe', 1980; Regoli et al., 1990; Hall, 1992). Of course, deletion of the arginine at the $9^{\text {th }}$ position of $\mathrm{BK}$ at the C-terminal, to produce des- $\mathrm{Arg}^{9}-\mathrm{BK}$, led to a $>4000$ times decrease in potency in the CEPI-17-CL4 cells. The low activity of des-Arg'-BK, which is a high affinity $\mathrm{B}_{1}$-receptor agonist (Regoli \& Barabe', 1980; Hall, 1992), in our human corneal cells suggested the identification of a $B_{2}$-receptor in these cells. This was further borne-out by the high potency of $\mathrm{BK}$ and Lys-BK and the potent antagonism of the BK-induced PI turnover in both P-CEPI and CEPI-17-CL4 cells by the $\mathrm{B}_{2^{-}}$ antagonists, Hoe-140 (Hock et al., 1991; Wirth et al., 1995) and D-Arg ${ }^{0}\left[\mathrm{Hyp}^{3}, \mathrm{Thi}^{5,8}\right.$, DPhe $\left.{ }^{7}\right]$-BK (Regoli et al., 1990; Hall, 1992). Again, the nanomolar potency of Hoe-140 and the micromolar potency of $\mathrm{D}-\mathrm{Arg}^{0}\left[\mathrm{Hyp}^{3}, \mathrm{Thi}^{5,8}\right.$, DPhe $\left.{ }^{7}\right]-\mathrm{BK}$ in our CEPI cells correlated well with data obtained from receptor binding studies (e.g. Sharif \& Whiting, 1991; 1993), and blockade of PI turnover (Sharif et al., 1988; Sharif \& Xu, 1996; Tritopea et al., 1993), calcium mobilization (Ransom et al., 1991; Smith et al., 1995), tissue contraction and other functional responses in animal and human cells and tissues (Regoli et al., 1990; Hall, 1992; Marceau et al., 1993; 1994; Wiemer \& Wirth, 1992).

While Hoe-140 was a competitive antagonist in the human corneal cell culture functional assays, it has been shown to exhibit both competitive (Hock et al., 1991) and non-competitive (Regoli et al., 1990; Sharma, 1993; Marceau et al., 1994) properties in several different cells and tissues. However, as described for many biological systems (Regoli et al., 1990; Wirth et al., 1991; Hall, 1992; Marceau et al., 1994), Hoe-140 was substantially more potent than D- $\mathrm{Arg}^{0}\left[\mathrm{Hyp}^{3}\right.$, $\left.\mathrm{Thi}^{5,8}, \mathrm{DPhe}^{7}\right]-\mathrm{BK}$ in antagonizing the BK-induced $\left.{ }^{3} \mathrm{H}\right]-\mathrm{IPs}$ accumulation in CEPI-17-CL4 cells. The molar potency of D-
$\operatorname{Arg}^{0}\left[\mathrm{Hyp}^{3}, \mathrm{Thi}^{5,8}{ }^{\mathrm{D}} \mathrm{DPhe} \mathrm{P}^{7}\right]-\mathrm{BK}(371 \mathrm{nM})$ in the CEPI-17-CL4 cells compared well with that observed in human trabecular meshwork cells (Sharif \& Xu, 1996), HSDM1C1 fibrosarcoma cells (Sharif \& Whiting, 1993), PC12 phaeochromocytoma cells (Ransom et al., 1991) and in several other cell-types and tissues (Regoli et al., 1990; Hall, 1992; Sharma, 1993). The fact that both Hoe-140 and D$\operatorname{Arg}^{0}\left[\mathrm{Hyp}^{3}, \mathrm{Thi}^{5,8}{ }^{,} \mathrm{DPhe}^{7}\right]$-BK were full antagonists in the CEPI cells, with no apparent partial agonist properties, again suggested that the $\mathrm{BK}$ receptors on these cells were of the $\mathrm{B}_{2-}$ type. Further supportive evidence for this conclusion is the finding that the $\mathrm{B}_{3}$-subtype, claimed to exist in the large airways, is insensitive to $\mathrm{B}_{2}$-antagonists (Farmer \& Burch, 1992), and apparent $B_{3^{-}}$and $B_{4}$-subtypes, claimed to exist in the opposum oesophageal longitudinal muscle, are actually stimulated by $\mathrm{B}_{2}$-antagonists (Saha et al., 1990; Sharma, 1993).

With respect to the possible physiological significance of our observations, the following aspects may be relevant. Thus, in view of the fact that appreciable quantities of BK and Lys-BK are released into the tear-film of ocular allergic patients (Proud et al., 1990), the present studies suggest that during such allergic reactions the corneal epithelium may represent at least one of the target tissues for these kinins on the ocular surface, in addition to the conjunctival epithelium (Sharif et al., 1996a,c). Although the consequences of activation of the $\mathrm{BK}$ receptor on the CEPI cells remains to be defined, it is pertinent to note that corneal epithelial cells release a variety of pro-inflammatory cytokines (Cubitt et al., 1993) in response to pro-inflammatory agents such as PAF (Bazan et al., 1994), interleukins (Cubitt et al., 1993) and also during the development of the pathology of pseudophakic bullous keratopathy (Rosenbaum et al., 1995). Thus, like many epithelial cells within the body (Sauder, 1990; McGee et al., 1992; Bedard et al., 1993), the CEPI cells may also be involved in amplifying the corneal allergic inflammatory cascade when activated by BK or Lys-BK by evoking the release of other pro-inflammatory agents (e.g. cytokines; Paegelow et al., 1995), as do other conjunctional mast cell mediators like histamine and PAF in human conjunctival epithelial cells (Sharif et al., 1996a,c). In addition, since BK is known to elicit fluid and ion secretion from many types of epithelial cells (see Regoli \& Barabe', 1980; Hall, 1992 for reviews), the CEPI cell BK receptor may have a similar role in the corneal epithelium, especially since corneal and conjunctival epithelial cells also produce and secrete mucins (Watanabe et al., 1995) into the tears to provide a protective film for the ocular surface. Since BK elicits pain in many inflammatory conditions (Dray \& Perkins, 1993), it is possible that BK and Lys-BK released into the tears in allergic conditions (Proud et al., 1990) may activate corneal sensory nerves to evoke corneal pain. In addition, since $\mathrm{BK}$ has potent mitogenic effects in many types of cells (see Hall, 1992), it is possible that the BK and Lys-BK released into the tears have an homeostatic role in stimulating repair of the corneal epithelium and surrounding tissues by inducing cell proliferation. Some of these and other physiological/pathological roles of BK in human CEPI and CEPI-17-CL4 cells are currently being investigated.

In it concluded that the primary and transformed human CEPI cells possess BK receptors coupled to phospholipase C which generates water soluble IPs, and that the PI turnover signalling mechanism is apparently unaffected by the SV40immortalization procedure. This information has greatly extended the similarity of the pharmacology of responses previously observed for histamine and PAF in these two human corneal cell types (Sharif et al., 1996b). The similar rank order of agonist potency of BK and its analogues, the similarity of the magnitudes of $\left[{ }^{3} \mathrm{H}\right]-$ IPs production, coupled with similar sensitivities to two structurally different BK-antagonists, strongly suggests that the BK receptors on P-CEPI and CEPI17-CL4 cells are pharmacologically very similar if not identical. In addition, the agonist and antagonist potencies and the 
specific blockade of BK-induced PI turnover in both cell types of $\mathrm{B}_{2}$-selective antagonists helped identify the $\mathrm{BK}$ receptor in these cells as the $\mathrm{B}_{2}$-subtype. Taken together, the CEPI-17CL4 cells appear to represent a good in vitro model of human corneal epithelium and may prove useful for further investigations of human corneal epithelial physiology, pharmacology and pathology.

\section{Note added in proof}

Recent studies have shown $\mathrm{BK}$ to potently $\left(\mathrm{EC}_{50}=8-20 \mathrm{nM}\right)$ stimulate intercellular calcium mobilization in the CEPI-17-CL4 cells, and these responses could be antagonized by Hoe- 140 .

\section{References}

ABELSON, M.B. \& SCHAEFER, K. (1993). Conjunctivitis of allergic origin: immunologic mechanisms and current approaches to therapy. Survey Ophthalmol., 38, 115-132.

ABDEL-LATIF, A.A. (1995). Phosphosinositide and arachidonic acid signalling systems in the mammalian iris. Prog. Retinal Eye Res., 14, $75-107$

ALLANSMITH, M.R. \& ROSS, R.N. (1988). Ocular Allergy. Clin. Allergy, 18, $1-13$.

ARAKI-SASAKI, K., OHSAKI, Y., SASABE, T., HAYASHI, K., WATANABE, H., TANO, Y. \& HANDA, H. (1995). An SV40immortalized human corneal epithelial cell line and its characterization. Invest. Ophthalmol. Vis. Sci., 36, 614-621.

ARUNLAKSHANA, O. \& SCHILD, H.O. (1959). Some quantitative uses of drug antagonists. Br. J. Pharmacol. Chemother., 14, 4858 .

BAZAN, H.E.P., TAO, Y. \& HURST, J.S. (1994). Platelet-activating factor antagonists and ocular inflammation. J. Ocular Pharmacol., 10, 319-327.

BEDARD, M., MACCLURE, C.D., SCHILLER, N.L., FRANCOEUR, C., CANTIN, A. \& DENIS, M. (1993). Release of interleukin-8, interleukin- 6 and colony stimulating factors by upper airway epithelial cells: implication for cystic fibrosis. Am. J. Cell. Mol. Biol., 9, 455-462.

BENEZRA, D., HEMO, I. \& MAFTZIR, G. (1990). In vivo angiogenic activity of interleukins. Arch. Ophthalmol., 108, 573-576.

BERRIDGE, M.J., DOWNES, C.P. \& HANLEY, M.R. (1982). Lithium amplifies agonist-dependent phosphatidylinositol responses in brain and salivary gland. Biochem. J., 206, 587-595.

BERRIDGE, M.J. \& IRVINE, R.F. (1984). Inositol trisphosphate, a novel second messenger in cellular signal transduction. Nature, 312, $315-321$

BEUERMEN, R.W., CROSSON, C.E. \& KAUFMAN, H.E. (ed.) (1989) Healing Processes in The Cornea: Advances in Applied Biotechnology Series, Vol. 1, London: Gulf Publishing Company.

BUTT, S.K., DAWSON, L.G. \& HALL, J.M. (1995). Bradykinin B receptors in the rabbit urinary bladder: induction of responses, smooth muscle contraction and phosphatidylinositol hydrolysis. Br. J. Pharmacol., 114, 612-617.

BYNKE, G., HAKANSON, R., HORIG, J. \& LEANDER, S. (1983). Bradykinin contracts the pupillary sphincter and evokes ocular inflammation through release of neuronal substance P. Eur. J. Pharmacol., 91, 469-475.

CHENG, Y.C. \& PRUSOFF, W.H. (1973). Relationship between the inhibition constant $\left(\mathrm{K}_{\mathrm{i}}\right)$ and the concentration of inhibitor which causes 50 percent inhibition $\left(\mathrm{IC}_{50}\right)$ of an enzymatic reaction. Biochem. Pharmacol., 22, 3099-3108.

COLE, D.F. (1974). The site of breakdown of the blood-aqueous barrier under the influence of vasodilator drugs. Exp. Eye Res. 19, $591-607$.

COLE, D.F. \& UNGAR, W.G. (1974). Action of bradykinin on intraocular pressure and pupillary diameter. Ophthalmol. Res., 6, $308-314$.

CUBITT, C.L., TANG, Q., MONTERIO, C.A., LAUSCH, R.N. \& OAKES J.E. (1993). IL-3 gene expression in cultures of human cornea epithelial cells and keratocytes. Invest. Ophthalmol. Vis. Sci., 34, $3199-3206$

DRAY, A. \& PERKINS, M. (1993). Bradykinin and inflammatory pain. Trends Neurosci., 16, 99-104.

ELLIOTT, P.J., MACKIC, J.B., GRANEY, W.F., BARTUS, R.T. \& ZLOKOVIC, B.V. (1995). RMP-7, bradykinin agonist, increases permeability of blood-ocular barriers in the guinea pig. Inves. Ophthal. Vis. Sci., 36, $2542-2547$.
The authors are grateful for the generous supply of the CEPI-17CL4 cells from Dr A.M.A. Pfeifer (Nestle, Lausanne, Switzerland). We also thank Dr W.E. Howe (Alcon) and Dr D. Dimitrijevich (University of North Texas, Health Sciences Center, UNTHSC, Fort Worth, Texas) for help with primary cell culture techniques. Dr M. Martin and Dr T. Yorio (UNTHSC) are thanked for critically reading the manuscript and for their helpful comments

FARMER, S.G. \& BURCH, R.M. (1992). Biochemical and molecular pharmacology of kinin receptors. Ann. Rev. Pharmacol. Toxicol. 32, $511-536$.

FIGINI, M., JAVDAN, P., CIONCOLINI, F. \& GEPPETTI, P. (1995). Involvement of tachykinins in plasma extravasation induced by bradykinin and low $\mathrm{pH}$ medium in the guinea pig conjunctiva. $\mathrm{Br}$. J. Pharmacol., 115, $128-132$.

GAO, X., STEWART, J.M., VAVREK, R.J. \& GREENBAUM, L.M (1993). Characterization of receptor-mediated actions of Tkinin. Biochem. Pharmacol., 46, 1607-1612.

HALL, J.M. (1992). Bradykinin receptors: pharmacological properties and biological roles. Pharmacol. Ther., 56, $131-190$.

HALL, J.M., FIGINI, M., BUTT, S.K. \& GEPPETTI, P. (1995). Inhibition of bradykinin-evoked trigeminal nerve stimulation by the nonpeptide bradykinin $\mathrm{B}_{2}$ receptor antagonist WIN-64338 in vivo and in vitro. Br. J. Pharmacol., 116, 3164-3168.

HOCK, F.J., WIRTH, K., ALBUS, U., LINZ, W., GERHARDS, H.J., WIEMER, G., ST. HENKE, G., BREIPOHL, G., KONIG, W. KNOLLE, J. \& SCHOLKEN, B.A. (1991). Hoe-140 a new potent and long acting bradykinin-antagonist: in vitro studies. $\mathrm{Br} . \mathrm{J}$. Pharmacol., 102, $769-773$.

KAHN, C.R., YOUNG, E., LEE, I.H. \& REHM, J.S. (1993). Human corneal epithelial primary cultures and cell lines with extended life span: in vitro model for ocular studies. Invest. Ophthalmol. Vis. Sci., 34, 3429-3441.

MA, J-X., SONG, Q., HATCHER, H.C., CROUCH, R.K., CHAO, L. \& CHAO, J. (1996). Expression and cellular localization of the kallikrein-kinin system in human ocular tissues. Exp. Eye. Res., 63, $19-26$.

MARCEAU, F. (1995). Kinin $\mathrm{B}_{1}$ receptors: A review. Immunopharmacology, 30, $1-26$.

MARCEAU, F., LEVESQUE, L., DRAPEAU, G., RIOUX, F., SALVINO, J.M., WOLFE, H.R., SOEANE, P.R \& SAWUTZ, D. G. (1994). Effects of peptide and nonpeptide antagonists of bradykinin $\mathrm{B}_{2}$ receptors on the venoconstrictor action of bradykinin. J. Pharmacol. Exp. Ther., 269, $1136-1143$.

MARCEAU, F., LUSSIER, A., REGOLI, D. \& GIROUD, J.P. (1993) Pharmacology of kinins: their relevance to tissue injury and inflammation. Gen. Pharmacol., 14, 209-229.

MCGEE, D.W., BEAGLEY, K.W., AICHER, W.K. \& MCGHEE, J.R (1992). Transforming growth factor- $\alpha$ enhances interleukin-6 secretion by intestinal epithelial cells. Immunology, 77, 7-12.

MICHEL, A.D. \& WHITING, R.L. (1984). Analysis of ligand binding data using a microcomputer. Br. J. Pharmacol., 83, 460P.

OFFORD, E.A., TROMVOUKIS, Y., HOWE, W.E., SHARIF, N.A. \& PFEIFER, A.M.A. (1997). Establishment of an SV-40 immortalized human corneal epithelial cell-line with cytokeratin, cytokine, growth and metabolic enzyme expression similar to corneal epithelium. Exp. Eye Res., (in press).

PAEGELOW, I., WERNER, H., VIETINGHOFF, G. \& WARTNER, U. (1995). Release of cytokines from isolated lung strips by bradykinin. Inflamm. Res., 44, 306-311.

PFEIFER, A.M.A., COLE, K.E., SMOOT, D.T., WESTON, A., GROOPMAN, J.D., SHIELDS, P.G., VIGNAUD, J-M., JUILLERAT, M. LIPSKY, M.M., TRUMP, B.F., LECHNER, J.F. \& HARRIS, C.C. (1993). Simian virus 40 large tumour antigen-immortalized normal human liver epithelial cells express hepatocyte characteristics and metabolize chemical carcinogens. Proc. Natl. Acad. Sci. U.S.A., 90, $5123-5127$. 
PHAGOO, S.B., YAQOOB, M., BROWN, M.C.S. \& BURGESS, G.M (1996). Selective labelling of bradykinin receptor subtypes in W138 human lung fibroblasts. Br. J. Pharmacol., 119, 863-868.

PROIA, A.D. (1994). Inflammation. In Pathobiology of Ocular Disease, ed Garner, A. \& Klintworth, G.K., Chapter 2 pp. 63-99. New York: Marcel Dekker.

PROUD, D., SWEET, J., STEIN, P., SETTIPANE, R.A., KAGEYSOBOTKA, A., FREIDLAENDER, M.H. \& LICHTENSTEIN, L.M. (1990). Inflammatory mediator release on conjunctival provocation of allergic subjects with allergen. J. Allergy Clin. Immunol., 85, 896-905.

RANSOM, J.T., CHERWINSKI, H.M., DUNNE, J.F., \& SHARIF, N.A. (1991). Flow cytometric analysis of internal calcium mobilization via a $\mathrm{B}_{2}$-bradykinin receptor on a subclone of PC-12 cells. $J$. Neurochem., 56, $983-989$.

REGOLI, D. \& BARABE', J. (1980). Pharmacology of bradykinin and related kinins. Pharmacol. Rev., 32, 1-46.

REGOLI, D., RHALEB, N-E., DION, S. \& DRAPEAU, G. (1990). New selective bradykinin receptor antagonists and bradykinin $\mathrm{B}_{2}$ receptor characterization. Trends Pharmacol. Sci., 11, 156-161.

ROSENBAUM, J.T., PLANCK, S.R., HUANG, X-N., RIC, L. \& ANSEL, J.C. (1995). Detection of mRNA for the cytokines, interleukin-1a, and interleukin-8, in corneas from patients with pseudophakic bullous keratopathy. Invest. Opthalmol. Vis. Sci., 36, 2151-2155.

SAHA, J.K., SENGUPTA, J.N. \& GOPAL, R.K. (1990). Effect of bradykinin on opposum oesophgeal longitudinal smooth muscle: evidence for novel bradykinin receptors. J. Pharmacol. Exp. Ther., 252, $1012-1020$.

SAUDER, D.N. (1990). The role of epidermal cytokines in inflammatory skin diseases. J. Invest. Dermatol., 95, 27S-28S.

SHARIF, N.A., CRIDER, J.Y., GRIFFIN, B.W., DAVIS, T.L. \& HOWE, W.E. (1997a). Pharmacological analysis of mast cell mediator receptors coupled to adenylate cyclase and phospholipase $\mathrm{C}$ on immunocytochemically-defined human conjunctival epithelial cells. J. Ocular Pharmacol. Ther., (in press).

SHARIF, N.A., HUNTER, J.C., HILl, R.G. \& HUGHES, J. (1988). Bradykinin-induced accumulation of $\left[{ }^{3} \mathrm{H}\right]$ inositol-1-phosphate in human embryonic pituitary tumor cells by activation of a $\mathrm{B}_{2}$ receptor. Neurosci. Lett., 86, 279-283.

SHARIF, N.A., OFFORD, E.A., TROMVOUKIS, Y., HOWE, W.E., GRIFFIN, B.W., WIERNAS, T.K. \& PFEIFER, A.M.A. (1997b). Immortalized human corneal epithelial (CEPI) cell for use in ocular inflammation and toxicity studies. Assoc. Res. Vision Opthalmol., Abst. \#1090.

SHARIF, N.A. \& WHITING, R.L. (1991). Identification of $\mathrm{B}_{2}$ bradykinin receptors in guinea pig brain regions, spinal cord and peripheral tissues. Neurochem. Int., 18, 89-96.

SHARIF, N.A. \& WHITING, R.L. (1993). The neuropeptide bradykinin stimulates phosphoinositide turnover in HSDM1C1 cells: $\mathrm{B}_{2-}$ antagonist-sensitive responses and receptor binding studies. Neurochem. Res., 12, 1313-1320.
SHARIF, N.A., WIERNAS, T.K., GRIFFIN, B.W., HOWE, W.E., OFFORD, E.A. \& PFEIFER, A.M.A. (1997c). Similarity of the biochemical pharmacology of phospholipase C-coupled receptors for histamine, brakykinin and platelet-activating factor on immunocytochemically-defined primary and SV40-immortalized human corneal epithelial cells. Exp. Eye Res., (in press).

SHARIF, N.A. \& XU, S.X. (1996). Pharmacological characterization of bradykinin receptors coupled to phosphoinositide turnover in SV40-immortalized human trabecular meshwork cells. Exp. Eye Res., 63, $631-637$.

SHARIF, N.A., XU, S.X. \& YANNI, J.M. (1994). Emedastine: a potent, high affinity histamine $\mathrm{H}_{1}$-selective antagonist for ocular use. Receptor binding and second messenger studies. J. Ocular Pharmacol., 10, 653-664.

SHARIF, N.A., XU, S.X., MILLER, S.T., GAMACHE, D.A. \& YANNI, J.M. (1996). Characterization of the ocular anti-allergic and antihistaminic effects of olopatadine (AL-4943A), a novel drug for treating ocular allergic diseases. J. Pharmacol. Exp. Ther., 278, $1251-1260$.

SHARMA, J.N. (1993). Therapeutic prospects of bradykinin receptor antagonists. Gen. Pharmacol., 24, 267-274.

SMITH, J.A.M., WEBB, C., HOLFORD, J. \& BURGESS, G.M. (1995). Signal transduction pathways for $\mathrm{B}_{1}$ and $\mathrm{B}_{2}$ bradykinin receptors in bovine pulmonary artery endothelial cells. Mol. Pharmacol., 47, $525-534$

TIEN, X-Y., WALLACE, L.J., KACHUR, J.F., WON-KIM, S. \& GAGINELLA, T.S. (1990). Characterization of Ile-Ser-bradykinin-induced changes in short circuit current across rat colon. $J$. Pharmacol. Exp. Ther., 254, 1063-1067.

TRITROPEA, M.M., GUMMELT, D., HERZIG, M.S. \& LEEB-LUNDBERG, M.F. (1993). $B_{1}$ and $B_{2}$ kinin receptors on cultured superior mesenteric artery smooth muscle cells: receptor specific stimulation of inositol phosphate formation and arachidonic acid release by des-Arg ${ }^{9}$-bradykinin and bradykinin. J. Pharmacol. Exp. Ther., 264, 930-937.

WAHLESTEDT, C., BYNKE, G. \& HAKAnson, R. (1985). Pupillary constriction by bradykinin and capsaicin: mode of action. Eur. $J$ Pharmacol., 106, 577-583.

WATANABE, H., FABRICANT, M., TISDALE, A.S., SPURRMICHAUD, S.J., LINDBERG, K. \& GIPSON, I.L. (1995). Human corneal and conjunctival epithelia produce a mucin-like glycoprotein for the apical surface. Invest. Ophthalmol. Vis. Sci., 36, $337-344$.

WIEMER, G. \& WIRTH, K. (1992). Production of cyclic GMP via B $_{1}$ and $\mathrm{B}_{2}$ kinin receptors in cultured bovine aortic endothelial cells. J. Pharmacol. Exp. Ther., 262, 729-733.

WIRTH, K.J., HEITSCH, H. \& SCHOLKENS, B.A. (1995). Kinin receptor antagonists: unique probes in basic and clinical research. Can. J. Physiol. Pharmacol., 73, 797-804.

( Received December 4, 1996 Revised February 24, 1997 Accepted March 7, 1997) 